\title{
Bioethanol production of cheese whey in continuous culture
}

\section{Producción de bioetanol en cultivo continuo a partir de suero de leche}

\author{
SANDOVAL-SALAS, Fabiola†*, MÉNDEZ-CARRETO, Carlos, BARRALES-FERNÁNDEZ, \\ Christell and ORTEGA-AVILA, Graciela
}

Tecnológico Nacional de México/ITS de Perote, Laboratorio de Investigación

ID $1^{\text {st }}$ Author: Fabiola, Sandoval-Salas / ORC ID: 0000-0001-9267-4974, CVU CONACYT ID: 71814, SNI I

ID $1^{\text {st }}$ Co-author: Carlos, Méndez-Carreto / ORC ID: 0000-0002-2897-4453, CVU CONACYT ID: 227409

ID $2^{\text {nd }}$ Co-author: Christell, Barrales-Fernández / ORC ID: 0000-0002-9909-7572, CVU CONACYT ID: 697471

ID $3^{\text {rd }}$ Co-author: Graciela, Ortega-Avila / ORC ID: 0000-0002-9395-246X, CVU CONACYT ID: 1019267

DOI: $10.35429 /$ JOTI.2021.15.5.22.25

Received January 12, 2021; Accepted June 24, 2021

\begin{abstract}
The cheese industry produces a large amount of waste, the equivalent of 9L of cheese whey for every 10L of milk (Murari et al., 2018; Pendon et al., 2021; Sar et al., 2021). Whey is composed by lactose and proteins, mainly (Murari et al., 2018; Murari et al., 2019; Tesfaw et al., 2021). In most cases, cheese whey had not added value or specific use, being discarded and causing very important environmental implications (Maruri et al., 2018; Tesfaw et al., 2021; Sar et al., 2021). In the present study, the production of bioethanol from cheese whey were analyzed, using Kluyveromyces marxianus as inoculum, under continuous culture conditions $\left(28^{\circ} \mathrm{C}\right.$, agitation at 100 $\mathrm{rpm}$, aeration at $1 \mathrm{vvm}$, feed at $8.63 \mathrm{~mL} / \mathrm{min}$ ), where it was established that is possible to obtain yields of $0.62 \mathrm{~g}$ of ethanol per $\mathrm{g}$ of lactose in the first $18 \mathrm{~h}$, this makes it feasible for the continuous production of ethanol with cheese whey with minimal pretreatment.
\end{abstract}

Bioethanol, Cheese whey, Kluyveromyces marxianus

\begin{abstract}
Resumen
La industria quesera produce una gran cantidad de residuos, el equivalente $9 \mathrm{~L}$ de suero de leche por cada 10L de leche (Murari et al., 2018; Pendon et al., 2021; Sar et al., 2021). El suero de leche está compuesto por lactosa y proteínas, principalmente (Murari et al., 2018; Murari et al., 2019; Tesfaw et al., 2021). En la mayoría de los casos no se le da un valor agregado a este subproducto, siendo desechado y provocando implicaciones medioambientales importantes (Maruri et al., 2018; Tesfaw et al., 2021; Sar et al., 2021). En el presente estudio, se analizó la producción de bioetanol a partir de suero de leche, utilizando microorganismos a la variedad Kluyveromyces marxianus, en cultivo continuo, dónde se estableció que con las condiciones de operación establecidas $\left(28^{\circ} \mathrm{C}\right.$, agitación a $100 \mathrm{rpm}$ y aireación $1 \mathrm{vvm}$, alimentación de $8.63 \mathrm{~mL} / \mathrm{min}$ ) es posible obtener rendimientos de $0.62 \mathrm{~g}$ de etanol por $\mathrm{g}$ de lactosa en las primeras $18 \mathrm{~h}$, esto lo hace factible para la producción continua de etanol con suero de leche con mínimo de tratamiento previo.
\end{abstract}

Bioetanol, Suero de leche, Kluyveromyces marxianus

Citation: SANDOVAL-SALAS, Fabiola, MÉNDEZ-CARRETO, Carlos, BARRALES-FERNÁNDEZ, Christell and ORTEGA-AVILA, Graciela. Bioethanol production of cheese whey in continuous culture. Journal of Technical Invention. 2021. 5-15: 22-25

\footnotetext{
* Author Correspondence (e-mail: investiga.itspe @ gmail.com)

$\dagger$ Researcher contributing as first author.
} 


\section{Introduction}

The dairy industry consists of a complex range of products in the food industry, such as milk, cheese, yogurt, butter, cream, ice cream, among other derivatives of milk; However, this also implies that large amounts of waste are generated, becoming an environmental problem. As in the case of cheese production, where the amount of waste is equivalent to the same amount of substrate, that is, for every $10 \mathrm{~L}$ of milk, $1 \mathrm{Kg}$ of cheese and 9L of whey are obtained (Murari et al., 2018 ; Pendon et al., 2021; Sar et al., 2021).

Whey comes from the residual precipitation of milk casein, it is composed mainly of milk residues, such as lactose and proteins, in lesser amounts it contains fats, mineral salts and lactic acid (Murari et al., 2018 ; Murari et al., 2019; Tesfaw et al., 2021). In most cases, this by-product is not used or treated, so it is directly disposed of, having very important environmental implications around the world. In recent years, the possibility of using this by-product and giving it commercial interest has been explored, given its high lactose and protein content, in the production of permeates, concentrated whey protein, ethanol, electrical energy, biomass, biopolymers, enzymes and other value-added products (Saini et al., 2017; Maruri et al., 2018; Murari et al., 2019; Pendon et al., 2021; Tesfaw et al., 2021; Sar et al., 2021).

In the specific case of the production of bioethanol, obtained from whey, microorganisms with the ability to convert lactose have been studied. The varieties of the genus Kluyveromyces, Saccharomyces, Candida and some species of fungus are capable of using lactose as a carbon source, in addition to the fact that commercial use products such as biogas, ethanol, enzymes and biomass can be obtained for industrial use (Saini et al., 2017; Maruri et al., 2018; Pendon et al., 2021). However, the genus Kluyverimyces has turned out to be the most efficient when taking advantage of lactose, obtaining a conversion range of between $45 \%$ and $80 \%$, under different operating conditions (Maruri et al., 2018; Tesfaw et al. , 2021; Sar et al., 2021).
The Kluyveromyces marxianus variety has been widely studied to obtain bioethanol from lactose, due to its probiotic activity, thermotolerance, a high specific growth rate, resistance to acidic conditions and under nonaseptic conditions; Furthermore, in whey it has shown a significant advantage over other species, since it can grow in untreated, unsterilized, pasteurized or diluted sera (Saini et al., 2017; Murari et al., 2019; Pendon et al., 2021; Tesfaw et al., 2021; Sar et al., 2021).

Using whey for the production of bioethanol becomes a viable alternative for the use of this residue. That is why, in the present study, the production of bioethanol from whey was analyzed, using microorganisms to the variety Kluyveromyces marxianus, in continuous culture.

\section{Materials and methods}

\subsection{Microorganisms}

Kluyveromyces marxianus 837 was used, obtained from the national microbial collection of CINVESTAV (National Polytechnic Institute). They were stored in potato dextrose agar medium at $4{ }^{\circ} \mathrm{C}$.

\subsection{Inoculum}

$250 \mathrm{~mL}$ Erlenmeyer flasks were prepared with liquid YM medium, to which three roasts of $\mathrm{K}$. marxianus were inoculated and incubated for 24 h. From these flasks, $3 \mathrm{~mL}$ were inoculated into new Erlenmeyer flasks with liquid YM medium and allowed to incubate for $24 \mathrm{~h}$.

\subsection{Preparation of the medium for the reactor}

Sweet whey, deproteinized by heat treatment at $90^{\circ} \mathrm{C}$ for $20 \mathrm{~min}$, was used. Subsequently, it was filtered through a sky blanket of approximately $1 \mathrm{~mm}$ opening.

\subsection{Growth kinetics in batch culture}

For growth kinetics in batch culture, $2000 \mathrm{~mL}$ of deproteinized serum were taken and placed in a $3 \mathrm{~L}$ capacity reactor (Figure 1 ) and sterilized at $121^{\circ} \mathrm{C}$ for 17 minutes. It was inoculated with $\mathrm{K}$. marxianus at a rate of $1.7 \times 107$ cells $/ \mathrm{mL}$ and incubated for 21 hours, shaking at $100 \mathrm{rpm}$ and aeration at $1 \mathrm{vvm}$. 
Samples were taken every $3 \mathrm{~h}$ and towards the end of the kinetics, samples were taken every hour. As a control parameter, a direct cell count was performed in the Neubauer Chamber.

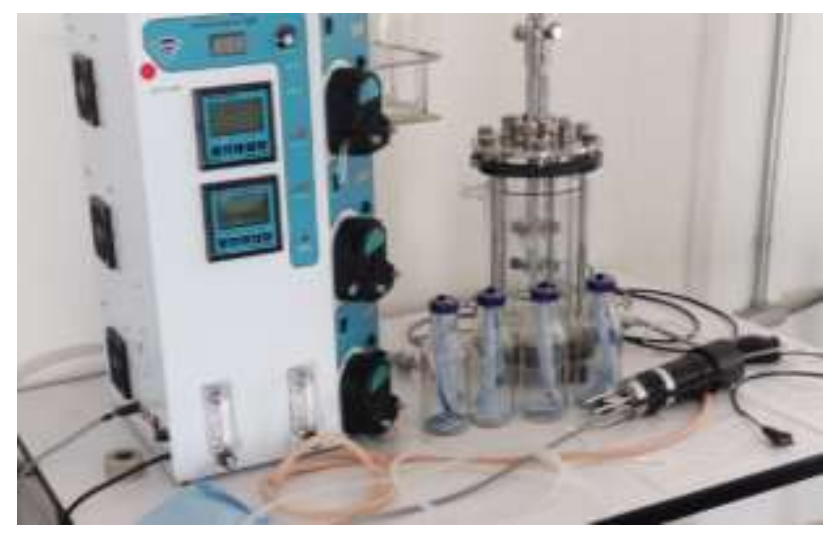

Figure 1 Semi-automatic fermentation reactor (SEV brand)

\subsection{Growth kinetics in continuous culture}

To start the growth kinetics in continuous culture, the specific growth rate was calculated using the general equation of microbial growth (equation 1):

$\ln x=\mu t+\ln x_{0}$

From the general Equation, the like terms are rearranged and integrated, to obtain the Equation of the specific growth rate. Where $\mu$ equals the growth rate and $t$ is time.

From the data obtained, it was determined that the dilution rate, being $0.259 \mathrm{~h}$ 1, and from Equation 2, it was determined that the feed flow was $8.63 \mathrm{~mL} / \mathrm{min}$.

$\mu=D=\frac{F}{V}$

Where $\mathrm{D}$, equals the dilution rate, $\mathrm{F}$, feed flow and $\mathrm{V}$, the volume of the reactor.

The feeding of the reactor was started at $18 \mathrm{~h}$ after the start of the first stage (section 2.4).

As a control parameter, ethanol production at the end of the $36 \mathrm{~h}$ incubation time and the direct cell count in the Neubauer Chamber were considered, taking samples every hour.

\section{Results and Discussion}

The behavior of the kinetics during batch culture is observed in Figure 2, the exponential phase of the same begins at $9 \mathrm{~h}$ and lasts until $9 \mathrm{~h}$.

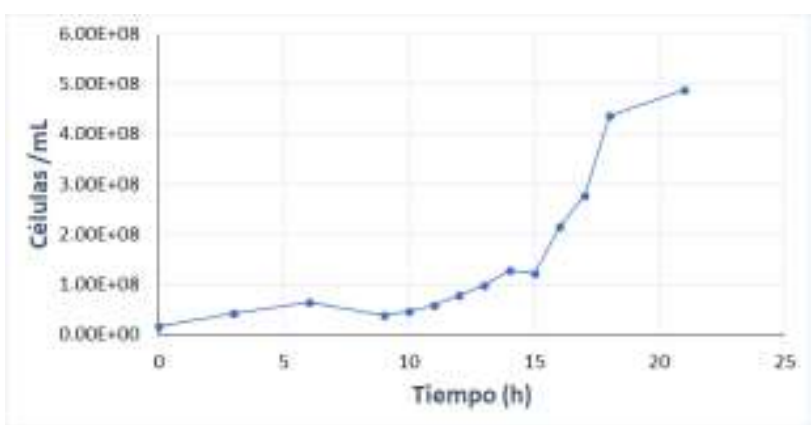

Figure 2 Batch Growth Kinetics for Whey Ethanol Production

The behavior of the exponential phase is observed in Figure 3, from which the specific growth speed was obtained and with it the feeding speed for the growth kinetics in continuous culture.

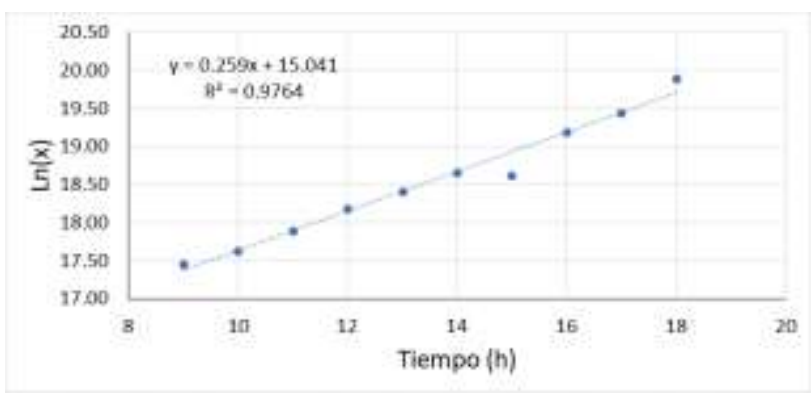

Figure 3 Determination of parameters for the production of ethanol from whey in continuous culture

With the results of the present study, it is observed that $\mathrm{K}$. marxianus yeast has the ability to use whey in the production of ethanol, being able to adapt to the characteristics of the serum and the kinetic conditions. The ethanol yield obtained was $0.62 \mathrm{~g}$ of ethanol per $\mathrm{g}$ of lactose. In a previous work, yields of up to $0.94 \mathrm{~g}$ of ethanol per gram of lactose were obtained (Sandoval-Salas et al., 2021), however, these results were obtained from treated whey, which increases production costs, Compared with the present study, a significant yield is observed for untreated whey, which can be used in the continuous production of ethanol.

The results are also comparable with the studies carried out by Saini et al. (2017), where they reported that with $\mathrm{K}$. marxianus ethanol yields of 2 to $3 \%$ were obtained, for this they used whey without previous treatment and under extreme conditions.

SANDOVAL-SALAS, Fabiola, MÉNDEZ-CARRETO, Carlos, BARRALES-FERNÁNDEZ, Christell and ORTEGA-AVILA, Graciela. Bioethanol production of cheese whey in continuous culture. Journal of Technical Invention. 2021 
On the other hand, Murari et al. (2018) and Tesfaw et al. (2021), used acid whey without treatment, and obtained ethanol yields of around 4.5 to $12.0 \mathrm{~g}$ of ethanol per liter of lactose.

\section{Conclusions}

Whey with minimal treatment is feasible for the production of bioethanol in continuous culture using K. marxianus, obtaining $0.62 \mathrm{~g}$ of ethanol for each $\mathrm{g}$ of lactose in the first 18 hours of operation. Said performance can be increased by adjusting and optimizing the operating conditions in the fermentation reactor.

\section{References}

Murari, C. S., da Silva, D. C. M. N., Schuina, G. L., Mosinahti, E. F., Del Bianchi, V. L. (2019). Bioethanol production from dairy industrial coproducts. BioEnergy Research, 12(1), 112122.

Murari, C. S., Machado, W. R. C., Schuina, G. L., \& Del Bianchi, V. L. (2019). Optimization of bioethanol production from cheese whey using Kluyveromyces marxianus URM 7404. Biocatalysis and Agricultural Biotechnology, 20, 101182.

Pendón, M. D., Madeira, J. V., Romanin, D. E., Rumbo, M., Gombert, A. K., Garrote, G. L. (2021). A biorefinery concept for the production of fuel ethanol, probiotic yeast, and whey protein from a by-product of the cheese industry. Applied Microbiology and Biotechnology, 105(9), 3859-3871.

Saini, P., Beniwal, A., Kokkiligadda, A., Vij, S. (2017). Evolutionary adaptation of Kluyveromyces marxianus strain for efficient conversion of whey lactose to bioethanol. Process Biochemistry, 62, 69-79.

Sandoval-Salas, F., Rendón-Ávila, A., AlemánChang, A. J., Méndez-Carreto, C., BarralesFernández, C. (2021). Producción de bioetanol a partir de suero de leche. Congreso Internacional de Desarrollo Sustentable y Energías Renovables (CIDSER), México.
Sar, T., Harirchi, S., Ramezani, M., Bulkan, G., Akbas, M. Y., Pandey, A., Taherzadeh, M. J. (2021). Potential utilization of dairy industries by-products and wastes through microbial processes: A critical review. Science of the Total Environment, Number 152253.

Tesfaw, A., Oner, E. T., Assefa, F. (2021). Evaluating crude whey for bioethanol production using non-Saccharomyces yeast, Kluyveromyces marxianus. SN Applied Sciences, 3(1), 1-8. 